\title{
RELEV ANSI HUKUMAN TAKZIR DALAM FIKIH DENGAN HUKUMAN SEBAGAI ALAT PENDIDIKAN
}

\author{
Oleh: M. Shabir U.*
}

\begin{abstract}
Constitutions or rules are implemented simply for human well-being, that is, to make possible human beings enjoy advantages at most and avoid any disorders. Those who disobey the rules will be sentenced. One model of punishment based on Islamic jurisprudence is "takzir". At the implementation stage of this model, the government or the judge should take both the condition of the doers and their cases into consideration. This is because punishment plays an important role as educational instrument. Despite this, some experts on education disagree with physical punishment, but they recommend other humane ways. In the field of education, students are punished in order that they do not commit the same mistakes again. This is in accordance with "takzir" in that it educates the offenders not to recommit the same mistakes in the future.
\end{abstract}

KEYWORDS: Syariat, kemaslahatan, hakim, hukuman, takzir, sanksi, alat pendidikan

BILA diteliti semua perintah dan larangan Allah swt. dalam Alquran serta perintah dan larangan Nabi saw. yang terumuskan dalam fikih akan terlihat bahwa semuanya mempunyai tujuan tertentu dan tidak ada yang sia-sia. Semuanya punya hikmah yang mendalam yaitu sebagai rahmat bagi semua manusia.

Allah swt. tidak menciptakan hamba-Nya begitu saja, tetapi Allah mengutus para nabi dan rasul-Nya sebagai pemberi kabar dan pemberi peringatan dan menurunkan kepada mereka kitab-kitab untuk memberi petunjuk bagi manusia kepada kebaikan dan kebahagiaan di dunia dan akhirat. Para ulama sepakat bahwa hukum Allah tegak ditujukan untuk kemaslahatan manusia.

\footnotetext{
*Magister Agama lulusan Program Pascasarjana UIN Alauddin Makassar, Konsentrasi Pendidikan Islam, ini adalah dosen pengampu mata kuliah Fikih pada Fakultas Tarbiyah dan Keguruan Universitas Islam Negeri Alauddin Makassar. Saat ini ia sedang menjabat sebagai Sekretaris Program Studi Islamic Studies pada Program Pascasarjana UIN Alauddin Makassar.
} 
Syariat yang diturunkan Allah swt. untuk manusia memiliki tujuan hukum tertentu, bukan dijadikan dengan sia-sia. Hal itu telah ditentukan dengan dalil-dalil dalam Alquran secara pasti sebagaimana firman-Nya dalam Q.S. al-Dukhkhān (44): 38-39 yang berbunyi:

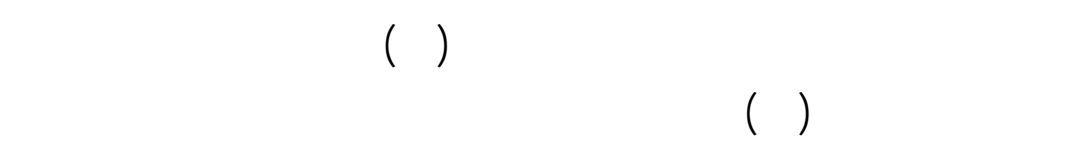

Dan kami tidak menciptakan langit dan bumi dan apa yang ada antara keduanya dengan bermain-main. Kami tidak menciptakan keduanya melainkan dengan haq, tetapi kebanyakan mereka tidak mengetahui.

Allah juga mengutus para rasul dan nabi dengan menurunkan syari'at-Nya untuk memberikan peraturan kepada manusia. Firman Allah dalam Q.S. al-Hadid (57): 25, yaitu:

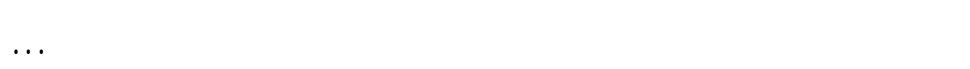

Sesungguhnya Kami telah mengutus rasul-rasul Kami dengan membawa bukti-bukti yang nyata dan telah kami turunkan bersama mereka al-Kitab dan neraca (keadilan) supaya manusia dapat melaksanakan keadilan.

Syariat Islam diturunkan untuk memberikan kemaslahatan kepada manusia, baik cepat maupun lambat, secara bersamaan yakni semua permasalahan dan akibat-akibatnya. Maslahah adalah mengambil manfaat dan menolak kemudaratan. Manfaat di sini tidak terbatas pada hal-hal yang materi saja, tetapi pada hal-hal yang maknawi juga yaitu sesuatu yang kembali pada tegaknya kehidupan manusia, sempurna hidupnya, tercapai apa yang dikehendaki oleh sifat syahwati dan akalnya secara mutlak. Jadi, tujuan syariat mencakup kemaslahatan dunia dan akhirat.

Tujuan syar'i sebagaimana disebutkan di atas ialah untuk mewujudkan kemaslahatan manusia, baik di dunia maupun di akhirat. Tujuan tersebut hendak dicapai melalui taklif yang pelaksanaannya tergantung pada pemahaman sumber hukum yang utama, Alquran dan hadis. Dalam mewujudkan kemaslahatan, berdasarkan penelitian ahli usul fikih, ada lima unsur pokok yang harus dipelihara dan diwujudkan, yakni agama, jiwa, akal, keturunan, dan harta. Seorang mukallaf akan memperoleh kemaslahatan manakala ia dapat memelihara kelima aspek pokok tersebut. Sebaliknya, ia akan merasakan adanya mafsadat manakala ia tidak dapat memelihara kelima unsur itu dengan baik.

Adapun yang dijadikan tolak ukur untuk menentukan baik dan buruknya (manfaat dan mafsadatnya) sesuatu yang dilakukan dan yang menjadi tujuan pokok pembinaan hukum itu adalah apa yang menjadi 
kebutuhan mendasar manusia. Tuntutan kebutuhan bagi manusia bertingkat-tingkat. Secara berurutan, peringkat itu adalah dharūriyyat (primer), häjiyyat (sekunder), dan tahsiniyyat (tersier). ${ }^{1}$ Yang dimaksud dengan dharūriyyat adalah memelihara kebutuhan-kebutuhan yang esensial dengan menjaga agama, jiwa, akal, keturunan, dan harta dari keterancaman eksistensinya. Kelima eksistensi ini disebut dharüriyyat al-khams.

Memelihara kelima hal primer tersebut dalam kehidupan manusia menjadi sendi eksistensi kehidupan manusia yang harus ada demi kemaslahatan mereka. Artinya, bila sendi-sendi itu tidak ada, kehidupan mereka akan kacau balau, kemaslahatan tidak tercapai dan kebahagiaan ukhrawi bakal tidak dapat dinikmati. Untuk itu, Islam telah menetapkan setiap hal dharūriyyat sejumlah hukum yang menjamin akan eksistensinya dalam bentuk hukum uqubat.

Kebutuhan dalam kelompok häjiyyat tidak termasuk kebutuhan yang esensial melainkan kebutuhan yang menghindarkan manusia untuk menghilangkan kesulitan-kesulitan dan menolak rintangan dalam hidupnya. Tidak terpeliharanya kelompok ini tidak mengancam eksistensi kelima pokok di atas, tetapi hanya akan menimbulkan kesulitan bagi mukallaf. Kelompok ini erat kaitannya dengan rukhshah dalam ibadah menurut ilmu fikih.

Prinsip utama dalam hal-hal hājiyyat adalah untuk menghilangkan kesulitan, meringankan beban taklif, dan memudahkan manusia dalam bermuamalah dan tukar-menukar manfaat. Untuk maksud itu, Islam telah menetapkan sejumlah ketentuan dalam muamalah, ibadah, dan pidana.

Sedangkan kelompok tahsiniyyat adalah tindakan antara lain sifat yang harus dijauhi oleh akal yang sehat, dipegangi oleh adat kebiasaan yang bagus dan dibutuhkan oleh kepribadian yang kuat. Kelompok ini merupakan kebutuhan yang menunjang peningkatan martabat seseorang dalam masyarakat dan di hadapan Allah sesuai dengan kepatutan. Bila tahsiniyyat ini tidak dapat dipenuhi, maka kehidupan manusia tidaklah sekacau sekiranya urusan dharūriyyat tidak diwujudkan dan tidak membawa kesusahan dan kesulitan seperti tidak terpenuhinya urusan häjiyyat manusia. Akan tetapi, hanya dianggap kurang harmonis oleh pertimbangan nalar sehat dan suara hati nurani.

Mengetahui urutan peringkat maslahat di atas menjadi penting artinya, apabila dihubungkan dengan skala prioritas penerapannya, ketika kemaslahatan yang satu berbenturan dengan kemaslahatan yang lain. Dalam hal ini, tentu peringkat pertama, darūriyyat, harus didahulukan daripada peringkat kedua, häjiyyat, dan peringkat ketiga, tahsiniyyat. Ketentuan ini menunjukkan bahwa dibenarkan mengabaikan hal-hal yang 
termasuk dalam peringkat kedua dan ketiga, manakala kemaslahatan yang masuk peringkat pertama terancam eksistensinya. Misalnya, seseorang diwajibkan untuk memenuhi kebutuhan pokok pangan untuk memelihara eksistensi jiwanya.

Demikian pula sebaliknya, tahsiniyyat dianggap sebagai penyempurna yang hājiyyat, dan häjiyyat merupakan penyempurna yang dharūriyyat. Siapa yang mengabaikan yang dharūriyyat, maka ia mengabaikan yang häjiyyat dan tahsiniyyat. Apabila ia mengabaikan yang hājiyyat dan tahsiniyyat, maka ia dikatakan dalam keadaan nyaris mengabaikan yang dharūriyyat.

Untuk menjamin terwujudnya kebutuhan mendasar manusia seperti yang disebutkan di atas-dharūriyyat (primer), hājiyyat (sekumder), dan tahsiniyyat (tersier)-maka siapapun yang melanggarnya akan diberi-kan sanksi, baik dalam bentuk had, qishash, maupun takzir.

Takzir merupakan salah satu bentuk hukuman yang dibebankan atas mukallaf yang melanggar hukum. Hukuman takzir adalah hukuman yang dijatuhkan berdasarkan pertimbangan hakim atau pemerintah terhadap pelanggaran yang tidak ditetapkan hukumannya secara tegas di dalam Alquran dan sunah atau terhadap pelanggaran yang sudah ditetapkan hukumannya, tetapi tidak memenuhi syarat hukuman tersebut dijatuhkan. ${ }^{2}$

Hukuman takzir dipandang sebagai hukuman pendidikan karena bertujuan agar pada diri pelakunya muncul efek jera. Ini sesuai dengan tujuan pemberian sanksi sebagai salah satu alat pendidikan. Tulisan ini akan mengungkap bagaimana relevansi hukuman takzir dalam Fikih dengan hukuman sebagai alat pendidikan.

\section{HUKUMAN TAKZIR}

\section{Pengertian Takzir}

Kata takzir berasal dari bahasa Arab هزر - عزير - kata dasarnya العآ والزاك وال راه

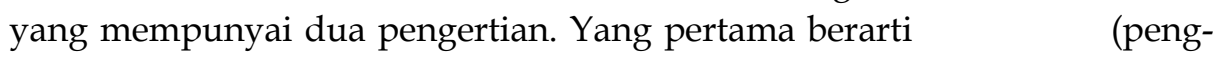

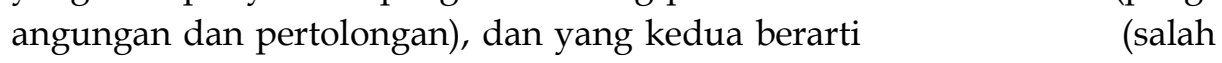

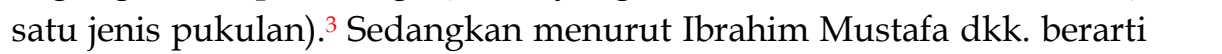
وأعاز ه (mencegah dari kejahatan dan menolongnya), dan juga dapat berarti وكن الثيك منء ه ورهه (melarang dari sesuatu dan mengembalikannya). ${ }^{4}$ Selanjutnya di dalam Kamus Besar Bahasa Indonesia dikemukanan bahwa takzir adalah hukuman yang dijatuhkan atas dasar kebijaksanaan hakim terhadap pelanggaran yang tidak ada ketentuan sanksinya di dalam Alquran dan hadis. ${ }^{5}$ 
Makna-makna kebahasaan tersebut dapat dilihat pemakaiannya pada beberapa ayat, misalnya dalam Q.S. al-Fath (48): 9 yang berbunyi:

\section{(9)}

Supaya kamu sekalian beriman kepada Allah dan Rasul-Nya, menguatkan (agama)-

Nya, membesarkan-Nya. dan bertasbih kepada-Nya di waktu pagi dan petang. ${ }^{6}$

Menurut istilah, takzir adalah tindak pidana yang tidak ditentukan sanksinya oleh Alquran maupun oleh hadis, misalnya tidak melaksanakan amanah, menghasab harta, menghina orang, menghina agama, menjadi saksi palsu, dan suap. ${ }^{7}$

Wahbah al-Zuhailiy memberi definisi takzir sebagai hukuman syar'i atas perbuatan maksiat atau kejahatan yang tidak ada hadnya dan tidak ada kafarat, baik kejahatan/pelanggaran terhadap hak Allah seperti berbuka pada siang hari bulan Ramadan tanpa uzur yang dibolehkan, meninggalkan salat, dan riba, maupun pelanggaran terhadap hak-hak manusia seperti menggauli wanita pada selain faraj (vagina), mencuri yang tidak sampai nisabnya, mengkhianati amanat, memanggil orang lain dengan panggilan tuduhan berbuat jahat seperti memanggil dengan kata-kata: "Hai pencuri, hai pezina, hai penjahat", dan lain-lain. ${ }^{8}$

Senada dengan al-Zuhailiy, Sayyid Sabiq memberi definisi takzir sebagai tindakan edukatif terhadap perilaku perbuatan dosa yang tidak ada sanksi had atau kafarat. ${ }^{9}$

Dari pengertian yang dikemukakan oleh para pakar di atas dapat dirumuskan bahwa takzir adalah hukuman yang bersifat edukatif yang dijatuhkan pada seseorang yang melakukan suatu tindak kejahatan yang bentuk hukumannya belum ditentukan secara tegas di dalam Alquran dan sunah, baik kejahatan itu berupa pelanggaran terhadap hak-hak Allah maupun pelanggaran terhadap hak-hak manusia sebagai hamba Allah.

Selain hukuman takzir dijatuhkan terhadap pelaku tindak kejahatan yang tidak ditentukan bentuk hukumannya oleh syarak (Alquran dan sunah), takzir juga dapat dijatuhkan terhadap pelaku tindak kejahatan atau pelanggaran terhadap undang-undang atau peraturan-peraturan yang dibuat oleh negara/pemerintah selama undang-undang atau peraturanperaturan tersebut tidak bertentangan dengan nilai-nilai, prinsip-prinsip, dan tujuan syariah. ${ }^{10}$ Di antara peraturan-peraturan yang dilanggar dan dapat dijatuhi hukuman takzir adalah peraturan lalu-lintas, pemeliharaan lingkungan hidup, aparat pemerintah yang tidak disiplin dan sebagainya.

Hukuman takzir juga dijatuhkan terhadap tindak kejahatan yang sudah ditentukan hukumannya di dalam Alquran atau sunah, baik berupa 
had, qishahs, maupun kafarat, tetapi tidak memenuhi syarat untuk menjatuhkan hukuman tersebut atas pelakunya karena adanya syubhat. ${ }^{11}$ Tindakan yang tidak boleh dihukum itu baik syubhat dalam kaitannya dengan pelaku, perbuatan, maupun dalam kaitannya dengan tempat. Hal ini dimaksudkan agar seseorang tidak dijatuhi hukuman atas dasar dzann atau dugaan saja karena sanksi hukum hanya boleh dijatuhkan setelah hakim betul-betul dapat membuktikan kesalahan seseorang secara meyakinkan.

Hukuman takzir merupakan hukuman yang bersifat edukatif, yakni yang berupa pemberian pelajaran. Dikatakan demikian karena hukuman tersebut sebenarnya bertujuan menghalangi pelakunya untuk kembali mengulangi kejahatan serupa atau dengan kata lain membuatnya jera.

Pemberlakuan hukuman takzir ditetapkan oleh pemerintah atau hakim yang bertindak sebagai wakil pemerintah di bidang penegakan hukum dengan mempertimbangkan beberapa hal. Di antara hal-hal yang dapat dijadikan sebagai bahan pertimbangan oleh hakim adalah besar kecilnya pelanggaran, adanya unsur sengaja atau kelalaian, baru pertama dilakukan atau sudah berkali-kali dan sebagainya.

\section{Bentuk-bentuk Hukuman Takzir}

Terdapat sejumlah bentuk hukuman takzir yang lazim dilakukan di antaranya sebagai berikut.

\section{Hukuman Takzir yang Berkaitan dengan Badan}

\section{Hukuman mati}

Mazhab Hanafi membolehkan takzir dengan hukuman mati dengan syarat pelanggaran itu sudah berulang-ulang dilakukan dan akan membawa kemaslahatan bagi masyarakat. Demikian pula Mazhab Maliki, Hanabilah, dan sebagian Mazhab Syafi'i ${ }^{12}$ membolehkan hukuman mati sebagai takzir yang paling tinggi seperti pada kasus spionase, pembuat kerusakan di bumi, dan homeseksual.

Di antara ulama ada pula yang tidak membolehkan hukuman mati sebagai takzir. Mereka hanya membolehkan hukuman mati bagi pezina muhsan, pembunuh, dan orang murtad dan meninggalkan jamaah.13 Tampaknya kalau melihat situasi saat ini yang mendukung kebolehan hukum mati lebih kuat, meskipun dalam pelaksanaan syaratnya harus diperketat dan hanya diberlakukan pada tindak kriminal yang sangat membahayakan dan meresahkan kemaslahatan masyarakat banyak, seperti para penyelundup dan pengedar narkoba. 


\section{Jilid (cambuk)}

Cambuk dalam hukuman takzir didasarkan pada Alquran, sunah dan ijma'. Misalnya, di dalam Q.S. al-Nisā' (4): 34 Allah berfirman:

\section{等

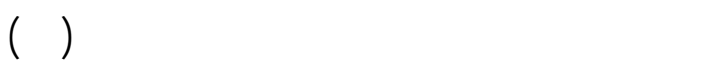

Wanita-wanita yang kamu khawatirkan nusyuznya, maka nasehatilah mereka dan pisahkanlah mereka di tempat tidur mereka, dan pukullah mereka. Kemudian jika mereka mentaatimu, maka janganlah kamu mencari-cari jalan untuk menyusahkannya. Sesungguhnya Allah Maha Tinggi lagi Maha Besar.

Dalam ayat tersebut disebutkan bahwa isteri-isteri yang durhaka boleh dipukul/didera, hanya saja dalam kasus ini yang memukul adalah suaminya.

Di antara contoh-contoh maksiat yang dikenai hukuman takzir dengan cambuk adalah pemalsuan stempel baitul mal pada zaman Umar ibn Khattab, percobaan perzinaan, pencuri yang tidak mencapai nishab, kerusakan akhlak, orang yang membantu perampokan, jarimah yang diancam dengan cambuk sebagai had tetapi terdapat syubhat. ${ }^{14}$

Ulama Hanafiyah membagi tingkatan manusia dalam kaitannya dengan takzir menjadi empat bagian, yaitu asyraf al-asyraf (orang yang paling mulia), al-asyraf (orang mulia), al-ausath (pertengahan), dan al-suflah (para pekerja kasar). ${ }^{15}$ Menurut mereka, orang yang termasuk kelompok keempat lebih efektif dijatuhi hukuman dera daripada hukuman denda.

Jumlah maksimal dan minimal hukuman cambuk dalam takzir diperdebatkan oleh para fuqaha. ${ }^{16}$ Namun demikian, secara umum mereka berpandangan bahwa pelaksanaan hukuman cambuk minimal harus dapat berdampak preventif dan represif bagi masyarakat dan banyaknya tidak boleh melebihi batas minimal jumlah cambukan dalam hukuman had.

\section{Hukuman Takzir yang Berkaitan dengan Kemerdekaan Seseorang}

\section{Al-Habs (penjara)}

Al-Habsu adalah menahan seseorang untuk tidak melakukan perbuatan hukum, baik tahanan itu di rumah, di masjid, maupun di tempat lain. Pada perkembangan selanjutnya, tempat tahanan ditetapkan di sebuah tempat yang sekarang disebut penjara.

Lama masa penahanan tidak disepakati oleh para ulama. Sebagian ulama seperti al-Mawardi menyerahkan kepada hakim. Sebagian ulama Syafi'iyah berpendapat bahwa batas terpanjang masa hukuman penjara adalah 1 tahun dengan mengqiyaskan kepada hukuman buang. Sementara itu sebagian ulama mengatakan batas minimalnya adalah satu hari. ${ }^{17}$ 
Di antara tindak kriminal yang pelakunya dijatuhi hukuman penjara adalah pelaku homoseksual, penculik, penyandera, penyihir, pencurian yang ketiga kalinya, pencuri yang tidak memenuhi satu nishab.

2. Hukuman buang/pengasingan

Sanksi buang sesungguhnya diancamkan kepada pelaku tindak kriminal hudud, tetapi ulama juga menerapkan kepada pelaku kejahatan takzir. Hukuman buang biasanya dijatuhkan kepada pelaku kriminal yang dikhawatirkan berpengaruh kepada orang lain.

Hukuman jenis ini tampaknya sudah tidak efektif lagi mengingat kemajuan teknologi informasi dan transportasi sudah sedemikian pesat. Hal ini menyebabkan efek jera tidak akan terwujud, kecuali kalau lokasi pembuangan itu adalah tempat yang tidak punya akses informasi dan transportasi.

\section{Hukuman Takzir yang Berupa Harta}

Yang dimaksud dengan hukuman takzir berupa harta adalah menahan, menghancurkan, mengubah, dan perampasan harta pelaku tindak kejahatan. Misalnya, penghancuran tempat-tempat arak atau maksiat lain, mengubah patung sesembahan dengan memotong kepalanya sehingga mirip tempat bunga, melipatgandakan buah-buahan yang dicuri sebagai denda, dan lain-lain.

Hukuman takzir bentuk ini tidak disetujui oleh seluruh ulama, tetapi mayoritas ulama menyetujui terhadap bentuk-bentuk tertentu dengan mengambil contoh-contoh yang dilakukan pada masa Rasulullah saw. dan para sahabat utama.

Selain ketiga bentuk takzir di atas, masih ada bentuk hukuman takzir lain yang lebih ringan, seperti dicela, dikucilkan, dinasehati, dipecat dari jabatannya, diumumkan kesalahannya, dan sebagainya. Kesemua bentuk takzir tesebut dijatuhkan oleh hakim dengan mempertimbangkan beberapa hal seperti disebutkan terdahulu dan dengan mempertimbangkan efek jera yang diharapkan muncul dari pemberlakuan hukuman takzir tersebut.

\section{HUKUMAN SEBAGAI ALAT PENDIDIKAN}

Dalam pembelajaran, yaitu dalam proses pembentukan kepribadian anak, dikenal apa yang disebut alat pendidikan. Alat pendidikan dipergunakan agar dalam pembentukan kepribadian anak itu dapat berjalan dengan baik. Alat-alat pendidikan yang dikenal di antaranya adalah contoh dan teladan, ancaman dan ganjaran, perintah dan larangan, serta hukuman. 
Alat pendidikan berupa hukuman kadang-kadang memang terpaksa harus digunakan. Dalam kaitan ini, ada beberapa teori tentang hukuman yang dianut oleh sebagian ahli pendidikan. Di antaranya adalah hukuman alam. Artinya, anak dihukum berdasarkan perbuatannya. Umpama main pisau dia terluka, memanjat dia terjatuh, dan mungkin patah tangannya. Hukuman alam ini bila dibiarkan akan berbahaya bagi si anak. Oleh karena itu, tidak banyak pendidik yang mempergunakan atau memakai teori ini. Ada lagi teori menjerakan, yakni anak dihukum agar ia tidak mengulangi perbuatan. Contohnya, bila terlambat datang ke sekolah, ia tidak diperkenankan mengikuti jam pelajaran di mana ia terlambat.

Dalam pendidikan, sanksi atau hukuman memiliki pengertian yang luas, mulai dari hukuman ringan sampai kepada hukuman berat, sejak kerlingan yang menyengat sampai pukulan yang agak menyakitkan. Menurut Ahmad Tafsir, sekalipun hukuman banyak macamnya, tetapi pengertian pokok dalam setiap hukuman tetap satu, yaitu adanya unsur yang menyakitkan, baik jiwa ataupun badan. ${ }^{18}$ Seiring dengan pengertian tersebut, M. Ngalim Purwanto mengemukakan bahwa hukuman adalah penderitaan yang diberikan atau ditimbulkan oleh seseorang (orangtua, guru dan sebagainya) sesudah terjadi suatu pelanggaran, kesalahan atau kejahatan. ${ }^{19}$

Sebagai alat pendidikan, pemberian hukuman itu dimaksudkan sebagai tuntunan dan perbaikan. Bukan sebagai hardikan atau balas dendam atas apa yang mereka kerjakan. Oleh karena itu, para pendidik hendaklah terlebih dahulu mempelajari tabiat serta sifat peserta didik sebelum dihukum, bahkan diajak supaya anak itu sendiri turut serta dalam memperbaiki kesalahan yang dilakukannya. Selain itu, suatu hukuman hendaklah senantiasa merupakan jawaban atas suatu pelanggaran, sedikit banyak tidak menyenangkan serta diberikan untuk kebaikannya sendiri.

Pada hakekatnya tidak ada ahli pendidikan yang menghendaki digunakannya hukuman dalam pendidikan kecuali bila terpaksa. Hadiah atau pujian jauh lebih dipentingkan ketimbang hukuman. Namun, bila keadaan amat memerlukan hukuman, maka hukuman itu harus digunakan dengan sangat hati-hati. Anak-anak jangan dicela dengan keras, tetapi dengan lemah lembut. Kadang-kadang raut wajah digunakan atau cara yang menggambarkan ketidaksenangan pada kelakuan anak.

Dalam kaitan ini, Ibn Sina berpendapat sebagaimana yang dikemukakan oleh al-Abrasyiy bahwa hukuman itu dilakukan bila keadaan memaksa, dan pukulan tidak digunakan kecuali sesudah diberi peringatan, ancaman, dan nasihat dengan maksud merangsang pengaruh yang diharapkan timbul dalam jiwa anak-anak itu. Pandangan ini tampaknya 
didasarkan kepada hadis Nabi saw. yang berbunyi:

\section{مروا اولادكم بالصلاة وهم ابناكسعسن] ولضروهم عليها وهم ابناء عشرسن]

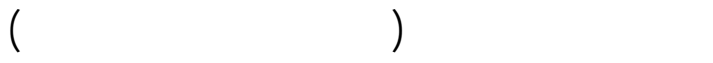

Perintahkanlah anak-anakmu salat ketika mereka berusia tujuh tahun dan pukullah mereka (bila tidak melaksanakan salat) ketika mereka berusia sepuluh tahun dan pisahkanlah mereka dari tempat tidur. ${ }^{20}$

Terkait dengan hal tersebut, Ibn Sina mengatakan, bila dipukul, hendaklah pukulan pertama kali menimbulkan rasa pedih pada peserta didik sehingga timbul efek yang diharapkan dan supaya ia jangan mengira enteng hukuman berikutnya. ${ }^{21}$

Ibn Khaldun tidak sependapat dengan Ibn Sina yang membolehkan menghukum anak dengan pukulan keras agar menjadi takut mengulangi perbuatannya. Ibn Khaldun menegaskan bahwa hukuman yang keras dalam pengajaran berbahaya bagi peserta didik, khususnya bagi anak-anak kecil. Menurutnya, tindakan itu dapat menyebabkan timbulnya kebiasaan buruk. Kekasaran dan kekerasan dalam pengajaran, baik terhadap muridmurid maupun hamba sahaya atau pelayan, dapat mengakibatkan bahwa kekerasan itu sendiri akan menguasai jiwa dan mencegah perkembangan pribadi anak yang bersangkutan. Kekerasan membuka jalan ke arah kemalasan dan keserongan, penipuan serta kelicikan. Misalnya, tindak tanduk dan ucapannya berbeda dengan yang di dalam pikiran karena takut mendapatkan perlakuan kejam atau kasar bila mereka mengucapkan yang sebenarnya. Dengan cara seperti itu, maka mereka seolah-olah diajari kelicikan dan kecurangan.

Kecenderungan-kecenderungan di atas kemudian menjadi kebiasaan dan watak yang berakar di dalam jiwa. Pada gilirannya ia merusak sifat kemanusiaan yang seyogyanya dipupuk melalui hubungan sosial dalam pergaulan dan juga merusak sikap perwira, seperti sikap mempertahankan diri dan keluarga. Orang-orang semacam ini akan menjadi beban orang lain sebagai tempat berlindung, dirinya menjadi malas dan enggan memupuk sifat keutamaan dan budi pekerti luhur. Mereka merasa dirinya kecil dan tidak mau berusaha menjadi manusia yang sempurna, lalu jatuh menjadi manusia yang hina. ${ }^{22}$

Dari uraian di atas tampak bahwa Ibn Khaldun telah cukup luas membentangkan pengaruh-pengaruh buruk yang dapat timbul disebabkan oleh kekerasan dan kekasaran dalam pendidikan. Hal ini dapat dilihat terutama ketika ia mengatakan bahwa siapa yang diperlakukan dengan kejam akan menjadi beban bagi orang lain, karena seseorang itu akan 
lemah dan tidak sanggup untuk membela kehormatan dirinya dan keluarganya disebabkan ia tidak lagi memiliki semangat dan kemauan, sedangkan keduanya penting untuk memiliki fadilah atau kehormatan dan moral yang baik. Dengan demikian, jiwanya telah menyimpang dari tujuan hidupnya dan rasa kemanusiaannya.

Satu hal yang perlu diingat bahwa yang sangat dilarang dalam dunia pendidikan adalah hukuman badan, termasuk memukul atau menampar anak didik. Apabila kita harus melaksanakan hukuman pada seorang anak, ada beberapa syarat yang harus kita penuhi. Pertama, menghukum tidak boleh dalam keadaan marah. Kedua, hukuman tidak boleh bersifat membalas dendam. Ketiga, hukuman harus ada hubungan dengan kesalahan, umpamanya mengotori lantai dia harus membersihkan lantai tersebut. Keempat, hukuman tidak boleh memalukan si anak.

Meskipun Ibnu Khaldun melarang pemberian hukuman dalam bentuk pukulan, ia tetap membolehkan jika terpaksa dengan mengikuti anjuran Muhammad ibn Abi Zayd yang mengatakan bahwa apabila anakanak terpaksa dipukul, maka guru maksimal boleh memukul sebanyak tiga pukulan. ${ }^{23}$ Itupun jangan sampai membekas pada badan si anak sebab maksud dari hukuman itu adalah untuk memperbaiki dan menyadarkannya dari kesalahan yang dilakukannya. Dengan demikian, ini berarti bahwa Ibn Khaldun juga tidak sependapat dengan ahli-ahli pendidikan modern, khususnya dari Barat yang mengkritik keras pendidik-pendidik Islam, dan sama sekali mengharamkan hukuman dalam bentuk pukulan. ${ }^{24}$

Jadi, kalau guru harus menghukum seorang anak, tenangkanlah diri, keluarlah dari kelas, tarik napas, dan bila sudah tenang masuklah kembali ke kelas dan laksanakanlah hukuman tersebut dengan mengikuti syaratsyarat tersebut di atas. Kalaupun hukuman badan akhirnya dengan sangat terpaksa dilakukan, maka harus dari pinggang ke bawah. Bagian-bagian lain dari tubuh sangat dilarang karena akan menyangkut kesehatan dan pertumbuhan anak di masa depan. Dan, yang menghukum adalah guru atau pendidik yang bersangkutan. Murid yang memukul kawannya justru harus dihukum oleh guru.

Suatu hukuman badani belum tentu menjadi obat yang mujarab untuk membasmi penyakit dan menyembuhkannya. Akan tetapi, sebaliknya hal itu mungkin menyebabkan semakin parahnya penyakit dan semakin berlanjutnya kesalahan. Hukuman moral dapat meninggalkan pengaruh mendalam pada jiwa anak-anak dan jauh lebih efektif daripada hukuman badan. Seorang murid yang terpilih untuk menjadi ketua kelas misalnya, melakukan pelanggaran lalu ia diberhentikan dan digantikan oleh murid yang lain. Bentuk hukuman moral ini mempunyai pengaruh psikologis yang cukup besar baginya sehingga ia berusaha keras bagai- 
mana agar dapat mengembalikan kepercayaan dari kawan-kawan dan guru-gurunya.

Dari uraian di atas tampaklah bahwa hukuman atau sanksi yang diberikan kepada anak didik merupakan salah satu alat pendidikan. Pemberian hukuman kepada anak didik dimaksudkan agar anak didik menyadari kelalaian dan kesalahannya sehingga pada diri mereka timbul efek jera dan tidak mau mengulang kelalaian atau kesalahan yang dibuatnya. Hal ini seiring dengan tujuan pemberian hukuman takzir dalam hukum Islam. Keduanya dijatuhkan dengan mempertimbangkan kondisi pelakunya dan kemungkinan timbulnya efek jera pada pelaku setelah hukuman itu ditimpakan atau dijatuhkan padanya.

\section{PENUTUP}

Semua perintah dan larangan Allah swt. dan Rasul-Nya mempunyai tujuan tertentu dan tidak ada yang sia-sia. Tujuan itu adalah mewujudkan kemaslahatan manusia berupa meraih manfaat dan menolak mudarat atau bahaya. Untuk mewujudkan kemaslahatn itu, maka ada tiga hal yang harus dipelihara oleh manusia, yaitu hal-hal yang dharūriyyat (primer), häjiyyat (sekunder), dan tahsiniyyat (tersier). Lalai dalam memelihara ketiga hal tersebut, maka ia akan mendapat hukuman, baik hukuman had, qishash, kafarat, maupun takzir.

Hukuman takzir adalah hukuman yang dibebankan kepada pelaku tindak kejahatan yang tidak ditetapkan hukumannya secara tegas di dalam Alquran dan sunah dengan tujuan untuk menimbulkan efek jera pada pelakunya. Bentuk hukuman ini diserahkan kepada pemerintah atau hakim dengan mempertimbangkan beberapa hal seperti berat ringan pelanggaran, sudah berulang atau baru, sengaja atau lalai, dan sebagainya. Hukuman takzir dapat berupa hukuman mati, cambuk, penjara, pengasingan, denda, pemberian nasehat, pengucilan dan sebagainya.

Alat pendidikan merupakan salah satu faktor penting dalam pendidikan yang teridiri dari beberapa macam. Di antaranya adalah pemberian hukuman. Para ahli pendidikan setuju menjadikan hukuman sebagai alat pendidikan. Namun, tidak semua setuju terhadap penggunaan kekerasan atau hukuman fisik. Ada yang melarang sama sekali, tetapi ada pula yang membolehkan selama tidak menyakiti apalagi bila sampai merusak fisik anak. Pemberian hukuman sebagai alat pendidikan ini bertujuan menyadarkan anak didik dari kesalahan dan membuatnya jera sehingga tidak mengulangi kesalahan di masa selanjutnya. Di sinilah letak persamaan atau relevansinya dengan hukuman takzir dalam fikih yang sama-sama menghendaki timbulnya efek jera, baik pada pelaku tindak kejahatan maupun pada anak didik yang melakukan kesalahan. 


\section{CATATAN AKHIR:}

1. Lihat Mukhtar Yahya dan Fatchurrahman, Dasar-dasar Pembinaan Hukum Figh Islami, cet. 1; Bandung: PT. Al-Ma'arif, 1986, h. 333-337.

2. Lihat A. Djazuli, Figh Jinayat (Upaya Menanggulangi Kejahatan dalam Islam), Jakarta: PT. Raja Grafindo Persada, 2000, h. 13. Lihat juga Wahbah al-Zuhailiy, Al-Figh al-Islamiy wa Adillatuh, juz VI, cet. III; Suriah: Dar al-Fikr, 1417 H./1996 M., h.197.

3. Abu al-Husain Ahmad bin Faris bin Zakariya, Mu'jam Maqāyis al-Lughah, juz IV, t.tp.: Ittihad al-Kitab al-Arabiy, 1423 H./ 2002 M., h. 253.

4. Ibrahim Mustafa, dkk. Al-Mu'jam al-Wasit, juz II, t.tp.: Majma' al-Lughah al'Arabiyyah, t.th., h. 102.

5. Tim Penyusun Kamus Pusat Bahasa, Kamus Besar Bahasa Indonesia, ed. 3, cet. III; Jakarta: Balai Pustaka, 2005, h. 1126.

6. Lihat juga ayat-ayat dalam Q.S. al-A'raf (7): 157 dan Q.S. al-Maidah (5): 12

7. A. Djazuli, Fiqh Jinayat (Upaya Menanggulangi Kejahatan dalam Islam), h. 163.

8. Lihat Wahbah al-Zuhailiy, Al-Figh al-Islamiy wa Adillatuh, juz VI, h. 197.

9. Sayyid Sabiq, Fiqh al-Sunnah, diterjemahkan oleh A. Ali dengan judul Fikih Sunah, jilid X, cet. VII; Bandung: PT. Al Ma'arif, 1995, h. 151.

10. Lihat A. Djazuli, Fiqh Jinayat, h. 163.

11. Lihat A. Djazuli, Fiqh Jinayat, h. 163.

12. Lihat Wahbah al-Zuhailiy, Al-Figh al-Islamiy wa Adillatuh, juz VI, h. 200-201.

13. Lihat A. Djazuli, Figh, h. 194.

14. Lihat Ibn Taimiyah, Al-Siyasah al-Syar'iyah fi Islah al-Ra'I wa al-Ra'iyah, t.tp.: Dar al-Kutub al-Rabiyah, t.th., h. 98. Lihat juga Mansur al-Buhutiy, Kasyf al-Qina', juz VI, t.tp.: Mathba'ah al-Hukumah, 1394 H., h. 121.

15. Abd al-Aziz Amir, Al-Ta'zīr fì al-Syarī’ah al-Islāmiyyah, cet. IV; Misr: Dar al-Fikr al-'Arabiy, 1969, h. 524-525.

16. Lihat pandangan-pandangan para fuqaha tentang batas minimal dan maksimal hukuman takzir dengan cambuk dalam A. Djazuli, Figh Jinayat (Upaya Menanggulangi Kejahatan dalam Islam), h. 197-200.

17. Lihat A. Djazuli, Fiqh, h. 206-207.

18. Ahmad Tafsir, Ilmu Pendidikan dalam Perspektif Islam, cet. I; Bandung: Remaja Rosdakarya, 1992, h. 186.

19. M. Ngalim Purwanto, Ilmu Pendidikan Teoretis dan Praktis, cet. VII; Bandung: Remaja Rosdakarya, 1994, h. 174

20. Lihat Jalal al-Din 'Abd al-Rahman ibn Abi Bakr al-Suyuthiy, Al-Jāmi' al-Shaghìr fi Ahādits al-Basyir al-Nadzir, Kairo: dar al-Katib al-Arabiy, 1967, h. 291.

21. Lihat Muhammad 'Athiyah al-Abrasyi, Al-Tarbiyyah al-Islämiyyah wa Falsafatuhā, cet. III; Misr: Isa al-Babiy al-Halabiy wa Syirkahu, 1975, h. 151.

22. Lihat 'Abd al-Rahman ibn Khaldun, Muqaddimah al-Allamah Ibn Khaldun, cet; IV; Bairut: Dar al-Kutub al-Ilmiyyah, 1978, h. 540.

23. 'Abd al-Rahman ibn Khaldun, Muqaddimah al-Allamah Ibn Khaldun, h. 540.

24. Hasan Langgulung, Manusia dan Pendidikan, cet. II; Jakarta: Pustaka al-Husna, 1989, h. 44. 


\section{DAFTAR PUSTAKA}

Al-Abrasyi, Muhammad 'Athiyah, Al-Tarbiyyah al-Islāmiyyah wa Falsa-fatuhā, cet. III; Misr: Isa al-Babiy al-Halabiy wa Syirkahu, 1975.

Amir, Abd al-Aziz, Al-Ta'zīr fi al-Syarīáah al-Islāmiyyah, cet. IV; Misr: Dar al-Fikr al'Arabiy, 1969.

Al-Buhutiy, Mansur, Kasyf al-Qina', juz VI, t.tp.: Mathba'ah al-Hukumah, 1394 H.

Djazuli, A., Figh Jinayat (Upaya Menanggulangi Kejahatan dalam Islam), Jakarta: PT. Raja Grafindo Persada, 2000.

Ibn Khaldun, 'Abd al-Rahman, Muqaddimah al-Allamah Ibn Khaldun, cet; IV; Bairut: Dar al-Kutub al-Ilmiyyah, 1978.

Ibn Taimiyah, Al-Siyāsah al-Syar'iyyah fi Islah al-Rā'i wa al-Rā'iyah, t.tp.: Dar alKutub al-Rabiyah, t.th.

Ibn Zakariya, Abu al-Husain Ahmad ibn Faris, Mu'jam Maqāyis al-Lughah, juz IV, t.tp.: Ittihad al-Kitab al-Arabiy, 1423 H./2002 M.

Langgulung, Hasan, Manusia dan Pendidikan, cet. II; Jakarta: Pustaka al-Husna, 1989.

Mustafa, Ibrahim, dkk. Al- Mu'jam al-Wasit, juz II, t.tp.: Majma' al-Lughah al'Arabiyyah, t.th.

Purwanto, M. Ngalim, Ilmu Pendidikan Teoretis dan Praktis, cet. VII; Bandung: Remaja Rosdakarya, 1994.

Sabiq, Sayyid, Figh al-Sunnah, diterjemahkan oleh A. Ali dengan judul Fikih Sunah, jilid X, cet. VII; Bandung: PT. Al Ma'arif, 1995.

Al-Suyuthiy, Jalal al-Din 'Abd al-Rahman ibn Abi Bakr, Al-Jāmi' al-Shaghìr fi Ahādits al-Basyir al-Nadzir, Kairo: dar al-Katib al-Arabiy, 1967.

Tafsir, Ahmad, Ilmu Pendidikan dalam Perspektif Islam, cet. I; Bandung: Remaja Rosdakarya, 1992.

Tim Penyusun Kamus Pusat Bahasa, Kamus Besar Bahasa Indonesia,ed. 3, cet. III; Jakarta: Balai Pustaka, 2005.

Yahya, Mukhtar dan Fatchurrahman, Dasar-Dasar Pembinaan Hukum Fiqh Islami, cet. 1; Bandung: PT. Al-Ma'arif, 1986.

Al-Zuhailiy, Wahbah, Al-Figh al-Islamiy wa Adillatuh, juz VI, cet. III; Suriah: Dar alFikr, 1417 H./1996 M. 